\author{
Research article
}

\title{
Hoya of Sumatra, an updated checklist, three new species, and a new subspecies
}

\author{
Sri RAHAYU ${ }^{1} \&$ Michele RODDA ${ }^{2, *}$ \\ ${ }^{1}$ Bogor Botanic Gardens, Indonesian Institute of Sciences, Bogor, Indonesia. \\ ${ }^{2}$ Herbarium, Singapore Botanic Gardens, National Parks Board, 1 Cluny Road, 259569, Singapore. \\ *Corresponding author: rodda.michele@gmail.com \\ ${ }^{1}$ Email: srirahayukrb@yahoo.com
}

\begin{abstract}
The list of the species of Hoya R.Br. occurring on the Indonesian island of Sumatra is updated and the type citation is clarified. Sixteen taxa are added to the latest checklist. Hoya danumensis subsp. amarii S.Rahayu \& Rodda subsp. nov., H. rigidifolia S.Rahayu \& Rodda sp. nov., H. solokensis S.Rahayu \& Rodda sp. nov., and H. sumatrana S.Rahayu \& Rodda sp. nov. are newly described. Hoya parviflora Wight, $H$. parvifolia Schltr., and $H$. purpureofusca Hook. are lectotypified.
\end{abstract}

Keywords. Apocynaceae, Asclepiadaceae, Asclepiadoideae, Indonesia, Marsdenieae.

Rahayu S. \& Rodda M. 2019. Hoya of Sumatra, an updated checklist, three new species, and a new subspecies. European Journal of Taxonomy 508: 1-23. https://doi.org/10.5852/ejt.2019.508

\section{Introduction}

Indonesia has been predicted to have the most diverse array of species of Hoya R.Br (Brown 1810; Kleijn \& van Donkelaar 2001). However, a full inventory of Hoya occurring in Indonesia is yet to be completed. Indonesia is an extremely large and diverse country and our plan is to complete an inventory and revision of the Indonesian Hoya working on seven separate geographical areas: Sumatra, Java, Kalimantan, Lesser Sunda Islands, Sulawesi, Maluku, and Indonesian New Guinea.

Recent papers on Indonesian Hoya were published by Kleijn \& van Donkelaar (2001), who revised the genus in central Sulawesi, where 13 species occur; by Rahayu \& Wanntorp (2012), who published a checklist and a key to the Hoya of Sumatra that included 27 species; and lastly by Lamb \& Rodda (2016), who published a checklist of the Bornean species including 72 species, 34 of which occurring in Kalimantan. The most recently published Hoya from Sumatra is H. fauziana subsp. angulata Rodda et al. (2018).

The present paper aims at updating the checklist and clarifying the type citation of all the taxa of Hoya from Sumatra. Three species and one new subspecies are newly published: H. danumensis subsp. amarii S.Rahayu \& Rodda subsp. nov., H. rigidifolia S.Rahayu \& Rodda sp. nov. (based on material identified by Rahayu \& Wanntorp (2012) as H. oblanceolata Hook.f.), H. solokensis S.Rahayu \& Rodda sp. nov., and H. sumatrana S.Rahayu \& Rodda sp. nov. 


\title{
Material and methods
}

The present paper is based on the examination of specimens at $\mathrm{B}, \mathrm{BO}, \mathrm{BM}, \mathrm{K}$, and SING, as well as JSTOR Global Plants (https://plants.jstor.org/, accessed on 24 Jul. 2018) and on field-collected plants cultivated at the Bogor Botanic Gardens. All names have been verified on International Plant Names Index (http://www.ipni.org/, accessed on 24 Jul. 2018) and TROPICOS (http://www.tropicos.org/, accessed on 24 Jul. 2018). All protologues and type citations have been verified on Biodiversity Heritage Library (https://www.biodiversitylibrary.org/, accessed on 24 Jul. 2018), JSTOR (https://www.jstor.org/, accessed on 24 Jul. 2018) or at the Singapore Botanic Gardens library. Heterotypic synonyms are indicated only when based on types from Sumatra. All acronyms for repositories follow Thiers (2019).

\section{Results}

\section{Checklist of the genus Hoya of Sumatra}

\author{
Class Magnoliopsida Brongn. \\ Subclass Asteridae Takht. \\ Order Gentianales Juss. ex Bercht. \& J.Presl \\ Family Apocynaceae Juss. \\ Genus Hoya R.Br. \\ Hoya andalensis Kloppenb.
}

Fraterna 18 (1): 1 (Anonymous 2005).

\section{Type material}

\section{Holotype}

INDONESIA - Sumatra, Padang, Air Sirah; in a young secondary forest; cultivated in USA, California, Fresno, vouchered on 19 Aug. 2004; UC n.v.

\section{Hoya beccarii Rodda \& Simonsson}

Webbia 68: 13 (Rodda \& Simonsson Juhonewe 2013).

\section{Type material}

\section{Holotype}

MALAYSIA • Sarawak, Matang; Jul. 1866; O. Beccari 6536a leg.; FI.

\section{Isotype}

MALAYSIA • Same data as for the holotype; FI.

\section{Hoya brooksii Ridl.}

Bulletin of Miscellaneous Information 1925: 85 (Ridley 1925).

\section{Type material}

Lectotype (designated by Turner et al. 2018)

INDONESIA • Sumatra, Lubuk Tandai; Jun. 1922; C.J. Brooks 7615 leg.; K000613013. 


\section{Hoya campanulata Blume}

Bijdragen tot de flora van Nederlandsch Indië: 1064 (Blume 1826). - Cystidianthus campanulatus (Blume) Hasskarl, Adnotationes de Plantis quibusdam Javanicis nonnullisque japonicis, haud rite cognitis, e Catalogo Horti Bogoriensis excerptae. Accedunt nunnullae Novae Species: 125 (Hasskarl 1843). - Physostelma campanulatum (Blume) Decne., Asclepiadeae: 633 (Decaisne 1844).

\section{Type material}

Lectotype (designated by Rodda et al. 2016)

INDONESIA • Java, “ex horto, mento septembre, Tjunkankan, Burangarang”; L0004389.

\section{Hoya caudata Hook.f.}

The Flora of British India 4: 60 (Hooker 1883).

\section{Type material}

Lectotype (designated by Rintz (1978), first step, and then by Rodda (2017), second step) MALAYSIA • Malacca, A.C. Maingay 1956 leg.; Kew distritribution no. 1128; K000895134.

\section{Isolectotypes}

MALAYSIA • Same data as for the lectotype; K000895133, L0004315.

\section{Hoya coriacea Blume}

Bijdragen tot de flora van Nederlandsch Indië: 1063 (Blume 1826).

\section{Type material}

Lectotype (designated by Rodda 2017)

INDONESIA • "In fruticetis ad pedem montis Salak" [Java, Salak]; L (sheet no. 898.168-117).

\section{Possible isolectotype}

INDONESIA • Same data as for the lectotype; P00639838.

\section{Hoya coronaria Blume}

Bijdragen tot de flora van Nederlandsch Indië: 1063 (Blume 1826). — Eriostemma coronaria (Blume) Kloppenb. \& Gilding, Fraterna 14 (2): 1 (Anonymous 2001).

\section{Type material}

Lectotype (designated by Kleijn \& van Donkelaar 2001: 469)

INDONESIA • Java; sine coll. "124/6" leg.; L (sheet no. 898.168-121).

\section{Isolectotype}

INDONESIA • Same data as for the lectotype; L (sheet no. 898.168-128). 
Hoya danumensis subsp. amarii S.Rahayu \& Rodda subsp. nov. urn:lsid:ipni.org:names:77194999-1

Figs $1 \mathrm{~A}-\mathrm{B}, 2 \mathrm{~A}-\mathrm{B}$

\section{Etymology}

The new species is named after Amar Husein Sitompul, who collected the type specimen.

\section{Type material}

\section{Holotype}

INDONESIA • Sumatra, North Sumatra, Padang Sidempuan; ca 900 m a.s.l.; 16 Sep. 2014; Amar Husein Sitompul s.n. leg.; BO.

\section{Description}

Epiphytic shrub, with white latex in all vegetative parts. Roots only basal, no adventitious roots observed. Stems erect or spreading, 4-6 $\mathrm{mm}$ in diameter, bright green, sparsely pubescent when young; older stems grey, glabrous; internodes 2-4(6) cm. Leaf blades 5-12 $\times 2.5-5 \mathrm{~cm}$, thin, not succulent, chartaceous when dry, broadly lanceolate to oblong, base rounded, apex acuminate or caudate, mid green on adaxial surface, pale green on abaxial surface, glabrous (sparsely pubescent when young), venation pinnate, midrib slightly depressed on adaxial surface, convex on abaxial surface, secondary veins 3-7 pairs, basal colleters absent; petioles 5-10 $\times 2-3 \mathrm{~mm}$, terete, channelled above, twisted, mid green, sparsely pubescent when young, otherwise glabrous. Inflorescences sciadioidal, convex, of 5-15 flowers, with peduncles extra-axillary, positively geotropic, unbranched, one at each node, producing flowers subsequently a few times, terete, $10-15 \times 1.5-2.5 \mathrm{~mm}$, green, sparsely pubescent when very young. Flowers with terete pedicels $2.5-3 \mathrm{~cm} \times 0.06-0.08 \mathrm{~mm}$, pale green, glabrous. Calyx lobes triangular, apex round, $1.5-2 \times 0.5-0.6 \mathrm{~mm}$, sparsely pubescent outside or glabrous, inside glabrous, ciliate; basal colleters $0.15-0.25 \times 0.15-0.2 \mathrm{~mm}$, one at each calyx sinus, ovoid. Buds globose, 5-ridged, dark brown or deep purple when young, turning green. Corolla shallowly campanulate, 20-23 mm in diameter; tube 9-11 mm long, creamy white, glabrous outside, pilose inside, basally densely pubescent; lobes $2-3 \times 11-12 \mathrm{~mm}$, very broadly triangular, valvate in bud, creamy white, glabrous outside, very sparsely pubescent inside, tip glabrous. Corona staminal $4-5 \mathrm{~mm}$ high, $10-12 \mathrm{~mm}$ in diameter, stiff and waxy-looking, white; lobes $4.5-5 \times 2.3-2.5 \mathrm{~mm}$, spreading, ovate, attached at the back of the anthers, inner process apiculate, not touching in the middle, outer process acute with a rounded tip, lobes with revolute margin underneath. Anthers ca $0.7 \times 0.5 \mathrm{~mm}$, ovate, with apical round membranaceous appendage covering the style-head apex. Pollinia 550-650 $\times 220-270 \mu \mathrm{m}$, oblong, with a round base and an obliquely truncated apex; pellucid margin present all along the outer edge; caudicles ca $280 \times 180$ $\mu \mathrm{m}$, broadly triangular, almost transparent; corpusculum 300-350 $\times 100-120 \mu \mathrm{m}$, oblong; style-head 5 -angled in cross section, with five spreading lobes alternating with the stamens, style-head depressed with a central raised conical apex ca $0.5 \times 0.5 \mathrm{~mm}$ broad at the base, apex rounded; ovary 1.4-1.6 mm high, $0.3-0.4 \mathrm{~mm}$ in diameter, narrowly conical, apex acute. Fruit and seed not observed.

\section{Distribution and habitat}

Hoya danumensis subsp. amarii subsp. nov. is only known from the type locality in northern Sumatra, Indonesia, ca $900 \mathrm{~m}$ a.s.1.

\section{Conservation status}

Known only from a single collection and lacking information on the distribution area, the population size and the possible threats to the habitat, H. danumensis subsp. amarii is considered as Data Deficient (DD) (IUCN 2012). 

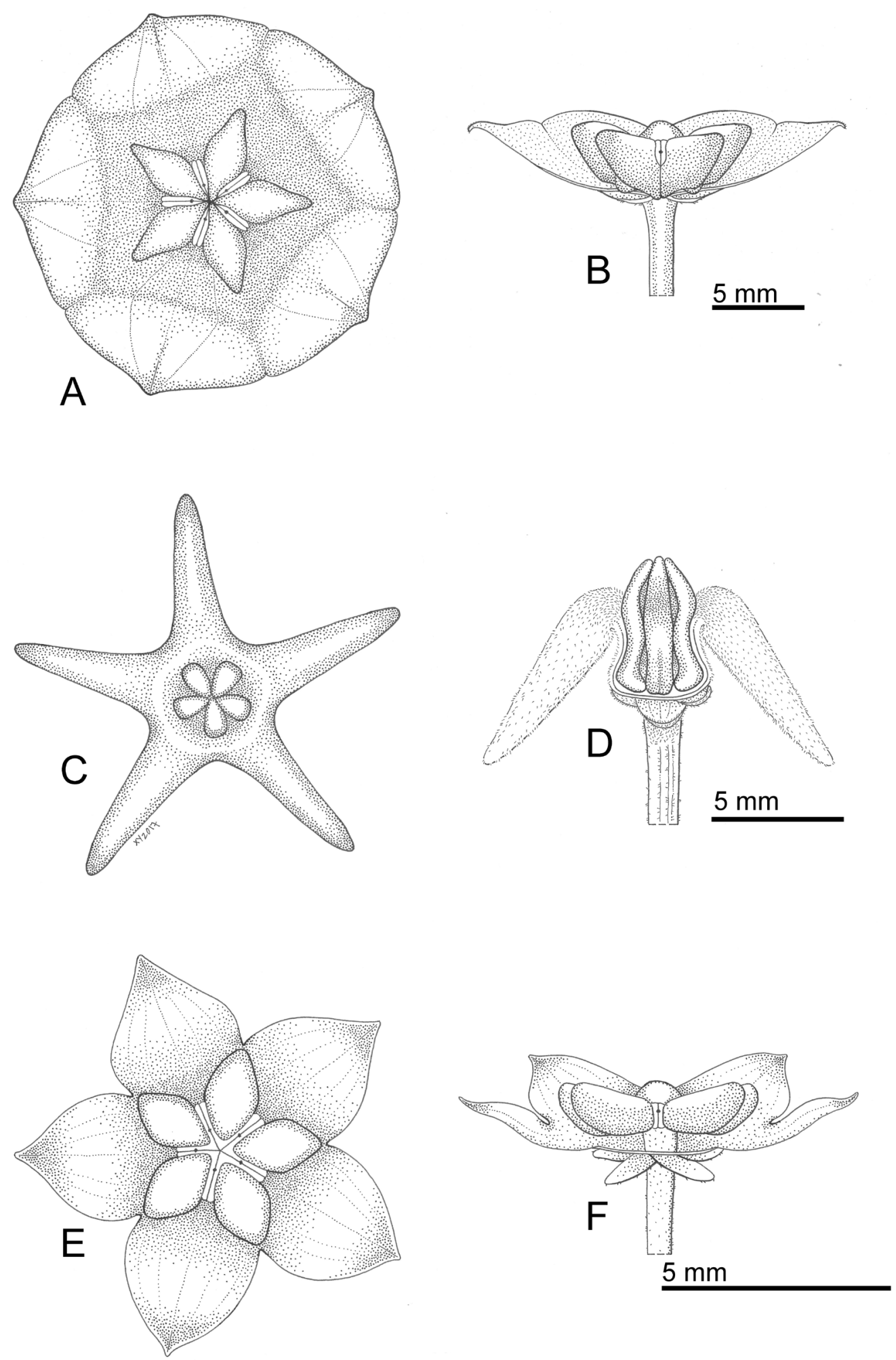

Fig. 1. Flowers. A, C, E. Top view of the flower. B, D, F. Side view of the flower, with part of corolla removed. A-B. H. danumensis subsp. amarii S.Rahayu \& Rodda subsp. nov. (Amar Husein Sitompul s.n. leg., BO). C-D. H. solokensis S.Rahayu \& Rodda sp. nov. (Fadly s.n. leg., BO). E-F. H. rigidifolia S.Rahayu \& Rodda sp. nov. (S. Rahayu 865 leg., BO). Drawing: X. Y. Loh. 

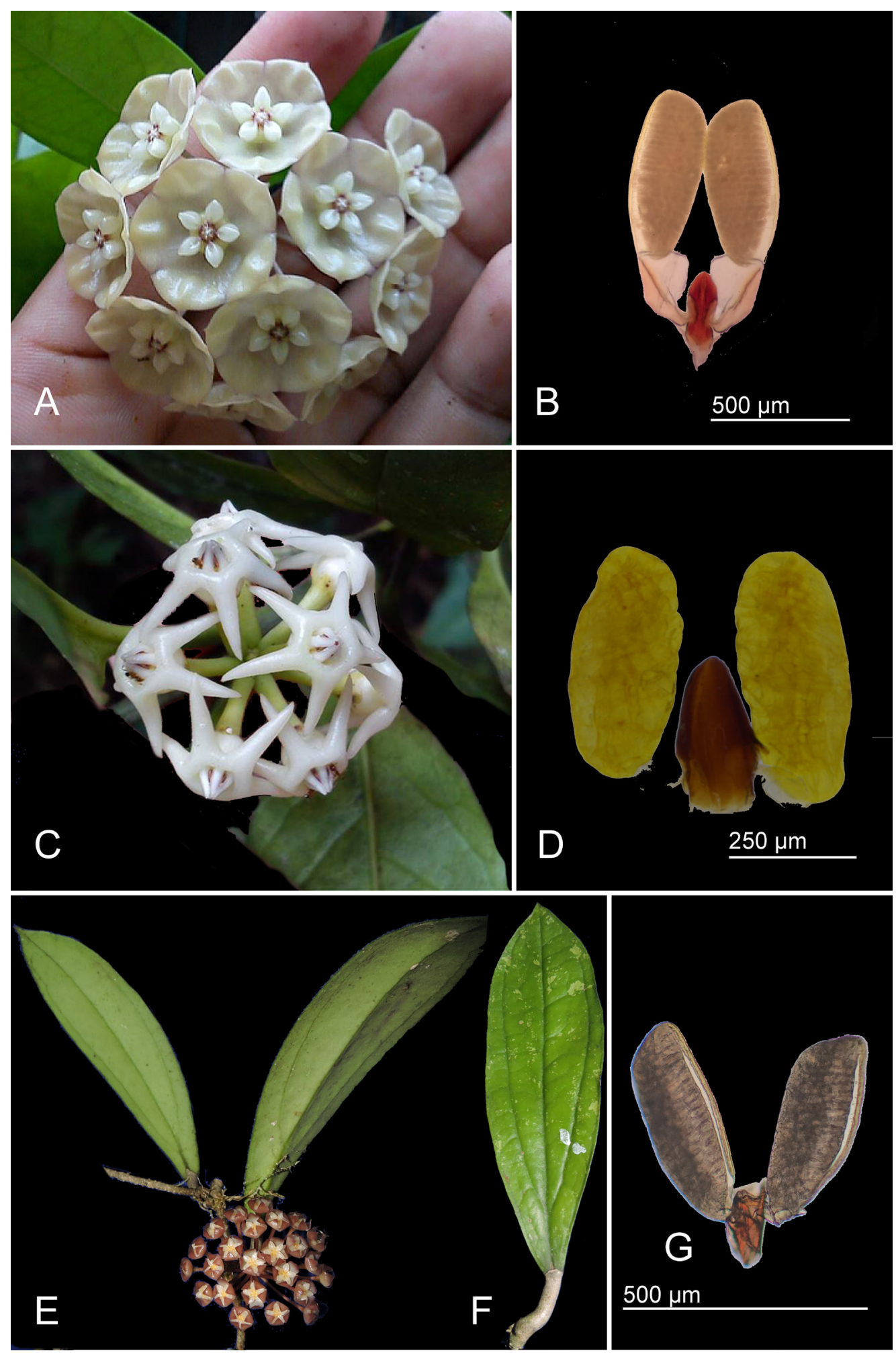

Fig. 2. Inflorescence, pollinarium, and leaf. A, C, E. Inflorescences. B, D, G. Pollinaria. F. Leaf. A-B. H. danumensis subsp. amarii S.Rahayu \& Rodda subsp. nov. (Amar Husein Sitompul s.n. leg., BO). C-D. H. solokensis S.Rahayu \& Rodda sp. nov. (Fadly s.n. leg., BO). E-G. H. rigidifolia S.Rahayu \& Rodda sp. nov. (S. Rahayu 865 leg., BO). Photos: Amar Husein Sitompul (A), Fadly (C), S. Rahayu (E-F), and M. Rodda (B, D, G). 


\section{Notes}

Hoya danumensis subsp. amarii subsp. nov. can be separated from H. danumensis Rodda \& Nyhuus (2009) subsp. danumensis because of the shape and size of the corolla that is shallowly campanulate, 20-23 mm in diameter and deeply campanulate, vs $25-35 \mathrm{~mm}$ in the latter; in the shape and size of the corona lobes that are ovate-oblong and 5.5-6 $\times 2.4-2.6 \mathrm{~mm}$ in $H$. danumensis subsp. danumensis vs ovate and $4.5-5 \times 2.3-2.5 \mathrm{~mm}$ in the new subspecies.

\section{Hoya deykeae T.Green}

Fraterna 13 (1): 15 (Green 2000) [published as “H. deykei”].

\section{Type material}

\section{Holotype}

INDONESIA - Sumatra; R. van Donkelaar \& D. Jannink 03-90 IPPS 4094 leg.; cultivated in USA, Hawaii, Oahu, Ka'a'awa, vouchered as 'T. Green 9903'; BISH1014777.

\section{Hoya diversifolia Blume}

Bijdragen tot de flora van Nederlandsch Indië: 1064 (Blume 1826).

\section{Type material}

Lectotype (designated by Rodda 2017)

Rumphius (1747: tab. 175 fig. 2).

Epitype (designated by Rodda 2017)

INDONESIA • "Hoya heterophylla"; L (sheet no. 989168-147).

\section{Hoya elliptica Hook.f.}

The Flora of British India 4: 58 (Hooker 1883).

\section{Type material}

Lectotype (designated by Rodda 2017)

MALAYSIA • Malacca; 1 Apr. 1868; A.C. Maingay 3286 leg.; Kew distribution no. 1137; K000895126.

\section{Isolectotype}

MALAYSIA • Same data as for the lectotype; K000895127.

Hoya fauziana subsp. angulata Rodda, A.L.Lamb, Gokusing \& S.Rahayu

Blumea 63: 144 (Rodda et al. 2018).

\section{Type material}

\section{Holotype}

MALAYSIA • Sabah, Tawau, Kalabakan area; 16 May 2017; L. Gokusing LG56/2017 leg.; mixed hill Dipterocarp forest; SAN.

\section{Hoya finlaysonii Wight}

Contributions to the Botany of India: 38 (Wight 1834). 


\section{Type material}

Lectotype (designated by Rodda 2017)

MALAYSIA • Penang?; ex herb. Finlayson, Wallich Asclepiad no. 42 (B = Wallich Catalogue 8166B); K000895121.

\section{Isolectotypes}

MALAYSIA • Same data as for the lectotype; K001129114, E00179577.

\section{Hoya forbesii King \& Gamble}

Journal of the Asiatic Society of Bengal 74 (2): 574 (King \& Gamble 1908).

\section{Type material}

Lectotype (designated by Rodda 2017)

INDONESIA • Sumatra, Kaba Volcano; 1881; H.O. Forbes 2896a leg.; K000894730.

\section{Hoya glabra Schltr.}

Botanische Jahrbücher für Systematik, Pflanzengeschichte und Pflanzengeographie 40 (92): 14 (Schlechter 1908).

\section{Type material}

Lectotype (designated by Rodda 2017)

INDONESIA • Borneo, Long Wahau; 2 Aug. 1901; R. Schlechter 13458 leg.; B100277199.

\section{Other material examined}

INDONESIA • Sumatra, Monkey reserve; $2^{\circ} 41.589^{\prime}$ N, 98 $9^{\circ} 55.656^{\prime}$ E; 1215 m a.s.l.; I.M. Liddle 1552 leg.; top of ridge; Singapore Botanic Gardens living collections no. 20123057, vouchered on 11 Feb. 2013 as 'M. Rodda MR286'; SING.

\section{Hoya imperialis Lindl.}

Edwards's Botanical Register 32: tab. 68 (Lindley 1846).

\section{Type material}

Lectotype (designated by Rodda 2017)

MALAYSIA? • Ex herb. J. Lindley [cultivated, from Sarawak via Lowe's Nursery]; CGE06041.

\section{Hoya kastbergii Kloppenb.}

Fraterna 16 (4): 1 (Anonymous 2003).

\section{Type material}

\section{Holotype}

MALAYSIA • Sarawak, Bau; I.S.A. Kastberg s.n. leg.; UC, missing.

Neotype (designated by Rodda 2017)

MALAYSIA • Sarawak, Bau, near Mulu National Park H.Q.; 23 Mar. 1981; I.S. Collenette 2357 leg.; L2726571. 


\section{Isoneotype}

MALAYSIA • Same data as for the neotype; $\mathrm{K}$.

\section{Hoya lacunosa Blume}

Bijdragen tot de flora van Nederlandsch Indië: 1063 (Blume 1826). - Otostemma lacunosum (Blume) Blume, Rumphia 4: 30 (Blume 1849b).

\section{Original citation}

"Circa Buitenzorg at arbores".

\section{Type material}

Lectotype (designated by Rodda 2017)

INDONESIA • "Hoya lacunosa"; L [sheet no. 898168-188].

Hoya lasiantha (Korth. ex Blume) Miq.

Flora van Nederlandsch Indie 2: 526 (Miquel 1857). - Plocostemma lasianthum Korth ex Blume, Museum Botanicum Lugduno-Batavum 1: 60 (Blume 1849a).

\section{Original citation}

"Ad montem Pamotton insulae Borneo".

\section{Type material}

Lectotype (designated by Rodda 2017)

MALAYSIA/INDONESIA? • Borneo; P. Korthals s.n. leg.; U1102625.

Epitype (designated by Rodda 2017)

Blume (1849a: fig. 14).

\section{Hoya latifolia G.Don}

A General History of the Dichlamydeous Plants 4: 127 (Don 1837). - H. macrophylla Wight, Contributions to the Botany of India: 38 (Wight 1834), non Blume, Bijdragen tot de flora van Nederlandsch Indië: 1063 (Blume 1826).

\section{Type material}

Lectotype (designated by Rodda 2017)

MALAYSIA • Penang; Wallich Asclepiad no. 138 (A = Wallich Catalogue 8161A); K000895124.

\section{Isolectotype}

MALAYSIA - Same data as for the lectotype; CGE (two sheets, one of which also containing leaves of H. mitrata), E00179576, K000895125.

\section{Hoya mitrata Kerr nom. cons.}

Hooker's Icones Plantarum 35: tab. 3406 (Kerr 1940). 


\section{Type material}

Lectotype (designated by Rintz 1978)

THAILAND • Surat, Ban Tong Tao; A.F.G. Kerr 13152 leg.; K.

\section{Hoya multiflora Blume}

Catalogus van eenige der merkwaardigste zoo in-als uit-heemsche gewassen, te vinden in 's lands plantentuin te Buitenzorg: 49 (Blume 1823). - Centrostemma multiflorum (Blume) Decne., Annales des Sciences naturelles, Botanique, sér. 2, 9: 272 (Decaisne 1838). - Cyrtoceras multiflorum (Blume) Heynh., Nomenclator Botanicus Hortensis: 183 (Heynhold 1840).

\section{Type material}

Lectotype (designated by Rodda 2017)

INDONESIA • Java, "prope flumine Tjapaes[?] Kietpil[?], Salleh”; 16 Sep. 1820; L2727033.

\section{Hoya obtusifolia Wight}

Contributions to the Botany of India: 38 (Wight 1834).

\section{Type material}

\section{Holotype}

MALAYSIA • Penang?; Wallich Asclepiad no. 38 (Wallich Catalogue 8167); K000895115.

\section{Isotypes}

MALAYSIA • Same data as for the holotype; E00179578, K001129115.

\section{Hoya omlorii (Livsh. \& Meve) L.Wanntorp \& Meve}

Willdenowia 41: 99 (Wanntorp \& Meve 2011). - Clemensiella omlorii Livsh. \& Meve, Edinburgh Journal of Botany 66 (3): 454 (Meve et al. 2009) [published as “Clemensiella omlori”].

\section{Type material}

\section{Holotype}

INDONESIA - Sumatra, Aceh, Gunung Leuser Reserve, Camp Simpang and vicinity; 19 Aug. 1972; W.J.J.O. de Wilde \& B.E.E. de Wilde-Duyfjes 14377 leg.; L.

\section{Isotype}

INDONESIA • Same data as for the holotype; K.

\section{Hoya parviflora Wight}

Contributions to the Botany of India: 37 (Wight 1834).

\section{Synonym}

H. variifolia Ridl., Bulletin of miscellaneous information, Royal Gardens, Kew 1926: 74 (Ridley 1926) syn. nov. Type: INDONESIA • Sumatra, Sipora; 27 Oct. 1924; C.B. Kloss 14793 leg.; K000894735 (holotype), SING005940 (isotype). 


\section{Type material}

Lectotype (designated here)

MYANMAR • "Maulmyne"; HRWP, Wallich Wall. Asclep. 33; K000895132.

\section{Hoya parvifolia Schltr.}

Botanische Jahrbücher für Systematik, Pflanzengeschichte und Pflanzengeographie 40 (92): 15 (Schlechter 1908).

\section{Type material}

Lectotype (designated here)

INDONESIA • Sumatra, Indragiri, auf Bäumen am Danau Kotta; 9 May 1901; R. Schlechter 13307 leg.; B100277226.

Hoya purpurascens Teijsm. \& Binn.

Natuurkundig Tijdschrift voor Nederlandsch Indië 25: 407 (Teijsmann \& Binnendijk 1863).

\section{Original citation}

"Sumatrae prov Lampong, Teijsmann" (type material not traced).

\section{Remarks}

This name is not recorded in Tropicos (http://www.tropicos.org, accessed on 24 Jul. 2018) and IPNI (http://www.ipni.org, accessed on 24 Jul. 2018) only records it as a nomen nudum (Teijsmann \& Binnendijk 1866). The species was validly published by Teijsmann \& Binnendijk (1863). Original material has been searched at $\mathrm{BO}, \mathrm{KRB}, \mathrm{L}$, and $\mathrm{U}$, but none has been found and it is possible that the species was described based on a live plant only.

\section{Hoya purpureofusca Hook.}

Botanical Magazine 76: tab. 4520 (Hooker 1850). - H. cinnamomifolia var. purpureofusca (Hook.) Kloppenb., Fraterna 14 (1): 12 (Kloppenburg 2001).

\section{Type material}

Lectotype (designated here)

INDONESIA • Java; T. Lobb s.n. leg.; cultivated [Veitch Nursery?]; K000894742.

Hoya revoluta Wight ex Hook.f.

The Flora of British India 4: 55 (Hooker 1883).

\section{Type material}

Lectotype (designated by Forster \& Liddle 1992b)

MALAYSIA • A.C. Maingay 1127 leg.; K000279860.

Epitype (designated by Rodda \& Simonsson Juhonewe 2013)

MALAYSIA • Pahang, Tasek Bera, low altitude; 14 Oct. 1930; M.R. Henderson 24439 leg.; SING. 


\section{Hoya rhodostele Ridl.}

Journal of the Malayan Branch of the Royal Asiatic Society 1: 77 (Ridley 1923).

\section{Type material}

Lectotype (designated by Turner et al. 2018)

INDONESIA • Sumatra, Berastagi; 8 Feb. 1921; H.N. Ridley s.n. leg.; K000894741.

\section{Additional type material}

INDONESIA • Sumatra, Berastagi; 13 Feb. 1921; H.N. Ridley s.n. leg.; K000894740.

\section{Hoya rigidifolia S.Rahayu \& Rodda sp. nov.}

urn:lsid:ipni.org:names:77195000-1

Figs $1 \mathrm{E}-\mathrm{F}, 2 \mathrm{E}-\mathrm{G}$

\section{Etymology}

The new species is named for its rigid and stiff leaves.

\section{Type material}

\section{Holotype}

INDONESIA - Sumatra, western Sumatra, Mentawai Islands, Pulau Siberut; 100 m a.s.l;; Aug. 2014; S. Rahayu 865 leg.; vouchered from live collection at Bogor Botanic Garden on 26 Sep. 2016 as 'S. Hidayat B9710110'; BO.

\section{Description}

Epiphytic climber, with white latex in all vegetative parts. Roots adventitious below the nodes and along the internodes. Stems climbing, 3-4 mm in diameter, dull brown, sparsely pubescent; older stems grey, glabrous; internodes 4-10 cm. Leaf blades 4-12(15) $\times 2.5-5 \mathrm{~cm}$, stiff and succulent, lanceolate to oblong, base acute, apex apiculate, mid to pale green on adaxial surface with sparse grey spots, pale green on abaxial surface with darker lines corresponding with the main vein and two prominent secondary veins, glabrous or sparsely pubescent when young, venation pinnate but with two prominent secondary veins running along the entire length of the lamina, and with a further 3-10 small secondary veins each side, primary and secondary veins depressed on adaxial surface, flat on abaxial surface; basal colleter ca $1 \times 1.5 \mathrm{~mm}$, one at each lamina base, broadly triangular, pale brown/cream; petioles 7-25 $\times 4-6 \mathrm{~mm}$, terete, thicker than stems, pale brown, sparsely pubescent when young. Inflorescences $3.5-4 \mathrm{~cm}$ in diameter, of 20-25 flowers, sciadioidal, convex; peduncles $15-30 \times$ ca $3 \mathrm{~mm}$, terete, extraaxillary, laterally held, one at each node, producing flowers over an extended period of time, brownish, sparsely pubescent. Flowers with terete pedicels $13-17 \times 0.7-1 \mathrm{~mm}$, pale brownish yellow, minutely papillose. Calyx lobes ovate or round, apex rounded, $1-1.5 \times 0.8-1 \mathrm{~mm}$, minutely papillose outside, glabrous inside, ciliate; basal colleters $250-300 \times 120-150 \mu \mathrm{m}$, ovoid, one at each calyx sinus. Corolla rotate, $10-12 \mathrm{~mm}$ in diameter when flattened; tube ca $1.5 \mathrm{~mm}$ long, cream inside, pale brown outside, glabrous; lobes 3.3-3.7 $\times 2.4-2.8 \mathrm{~mm}$, ovate, valvate in bud, with incurved acute tip, cream fading to pale brown at the tip inside, brown outside, glabrous. Corona staminal, $1.2-1.4 \mathrm{~mm}$ high, $3.7-4.2 \mathrm{~mm}$ in diameter, white; lobes $2-2.3 \times 1.1-1.2 \mathrm{~mm}$, attached at the back of the anthers, held at a ca $80^{\circ}$ angle, ovoid, slightly carinate above, inner process acute, erect, outer process rounded, spreading, with a basal revolute margin. Anthers ca $0.7 \times 0.6 \mathrm{~mm}$, ovate, including a thin apical round membranaceous appendage. Pollinia 350-400 $\times 130-150 \mu \mathrm{m}$, oblong, with a round base and an obliquely truncate apex; with a pellucid margin along the outer edge; caudicles ca $40 \times 20 \mu \mathrm{m}$, much reduced; corpusculum $120-140 \times$ ca $50 \mu \mathrm{m}$, oblong; style-head 5-angled in cross section, with five spreading lobes alternating 
with the stamens, style-head apex depressed with a central conical acute tip ca $200 \mu \mathrm{m}$ high; ovary $0.8-0.9 \mathrm{~mm}$ high, ca $0.35 \mathrm{~mm}$ in diameter at the base, conical, lightly curved, apex acute. Fruit and seed not observed.

\section{Distribution and habitat}

Hoya rigidifolia sp. nov. is only known from the type locality in the lowland forest of Pulau Siberut, southern Sumatra, Indonesia.

\section{Conservation status}

Known only from a single collection and lacking information on the distribution area, the population size and the possible threats to the habitat, $H$. rigidifolia sp. nov. is considered as Data Deficient (DD) (IUCN 2012).

\section{Notes}

Hoya rigidifolia sp. nov. flowers only open for a single day. The flowers of $H$. finlaysonii are also open for a single day and have a similar flower morphology (rotate corolla, ovoid corona lobes of similar size). Both species are, however, easily separated based on leaf characters. Hoya finlaysonii has lanceolate to oblong leaves with pinnate venation, usually darker than the rest of the lamina; H. rigidifolia sp. nov. also has pinnate venation, but additionally it has two basal secondary veins running along the entire length of the lamina. The leaf venation of H. erythrina Rintz (1978) is similar to that of H. rigidifolia sp. nov.; however, both species can be separated based on flower charaters: H. erythrina has flowers with corolla $>15 \mathrm{~mm}$ in diameter when flattened, long-pubescent inside, and lasting $>2$ days, while $H$. rigidifolia $\mathrm{sp}$. nov. has flowers with corolla $<12 \mathrm{~mm}$ in diameter when flattened, glabrous inside, and lasting one day.

\section{Hoya rintzii Rodda, Simonsson \& S.Rahayu}

Webbia 69: 44 (Rodda et al. 2014).

\section{Type material}

\section{Holotype}

MALAYSIA • Selangor, Sungai Langat; 3 Jun. 1976; R.E. Rintz RER61 leg.; KEP.

\section{Isotype}

MALAYSIA • Same data as for the holotype; K.

Hoya rundumensis (T.Green) Rodda \& Simonsson

Webbia 68: 13 (Rodda \& Simonsson Juhonewe 2013). - H. plicata subsp. rundumensis T.Green (Green 2010: 19).

\section{Type material}

\section{Holotype}

MALAYSIA • Sabah, Rundum; $3000 \mathrm{ft}$; cultivated in USA, Oahu, Ka'a'awa, Hawaii, garden of Ted Green, vouchered on 12 Aug. 2009 as 'T. Green 2010.001'; BISH1016412.

\section{Hoya sarcophylla Ridl.}

Journal of the Federated Malay States Museums 8 (4): 62 (Ridley 1917). 


\section{Type material}

Lectotype (designated by Turner et al. 2018)

INDONESIA • Sumatra, Korinchi, Siolak Daras; 3000 ft; 17 Mar. 1914; H.C. Robinson \& C.B. Kloss s.n. leg.; BM001190937.

Hoya scortechinii King \& Gamble

Journal of the Asiatic Society of Bengal 74 (2): 567 (King \& Gamble 1908).

\section{Type material}

Lectotype (designated by Rodda 2017)

MALAYSIA • Perak; B. Scortechini 464b leg.; K000895122.

\section{Hoya sigillatis T.Green subsp. sigillatis}

Fraterna 17 (3): 2 (Green 2004).

\section{Type material}

\section{Holotype}

MALAYSIA • Sabah, Tenom Agricultural Park; cultivated in USA, Hawaii, Oahu, Ka'a'awa, vouchered on unknown date as 'T. Green 91024'; BISH1014783.

Hoya solokensis S.Rahayu \& Rodda sp. nov.

urn:lsid:ipni.org:names:77195001-1

Figs $1 \mathrm{C}-\mathrm{D}, 2 \mathrm{C}-\mathrm{D}$

\section{Etymology}

The new species is named after the collection locality in Solok, Sumatra.

\section{Holotype}

INDONESIA•Sumatra, Solok; ca 1000 m a.s.1.; 10 Oct. 2016; Fadly s.n. leg.; BO.

\section{Description}

Epiphytic shrub, with white latex in all vegetative parts. Roots only basal, no adventitious roots observed. Stems erect or spreading, $2.5-5 \mathrm{~mm}$ in diameter, dull green, sparsely pubescent when young; older stems grey-brown, glabrous; internodes 1-2(5) cm. Leaf blades 5-10(12) $\times 2.5-4 \mathrm{~cm}$, thin, not succulent, chartaceous when dry, elliptic, base and apex acute or acuminate, mid green on adaxial surface, pale green on abaxial surface, glabrous, venation pinnate, midrib slightly depressed on adaxial surface, convex on abaxial surface, with 4-7 pairs of secondary veins, basal colleters absent; petioles 5-10 $\times$ 1.7-2 mm, terete channeled above, mid green, sparsely pubescent. Inflorescences sciadioidal, convex, of 3-10 flowers; peduncles $8-12 \times 1.2-1.4 \mathrm{~mm}$, extra-axillary, positively geotropic or horizontal, unbranched, one at each node, producing flowers only once, terete, green, sparsely pubescent just below the rachis, otherwise glabrous. Flowers with terete pedicels $5-8 \times 1-1.5 \mathrm{~mm}$, pale green, sparsely pubescent. Calyx lobes ovate- round, apex round, 1.4-2.2 $\times 1.2-1.6 \mathrm{~mm}$, light green, pubescent outside, glabrous inside, ciliate; basal colleters $1.5-2.3 \times 1.3-1.5 \mathrm{~mm}, 1-3$ at each calyx sinus, ovoid. Corolla tube basally bulbous, tightly enveloping the lower half of the corona, with a contracted throat, a short funnel-shaped tube and free, lanceolate, spreading lobes, white; basal bulbous part 2.5-3 mm high, 3-3.5 mm in diameter; free lobes 5-6 $\times 2.5-3 \mathrm{~mm}$, narrowly triangular, valvate in bud, with recurved edges and tip, tube pubescent inside with retrorse hairs, sparsely pubescent outside with spreading hairs, 
lobes sparsely pubescent inside and outside with spreading hairs. Corona staminal $4.5-5 \mathrm{~mm}$ high, $2.5-$ $3 \mathrm{~mm}$ in diameter, stiff and waxy-looking, white; lobes 4.5-5 $\times 1-1.2 \mathrm{~mm}$, erect, oblong and sinuose, attached at the back of the anthers, upper apicis rounded, touching in the middle, outer tips obtuse, with a narrow revolute margin. Anthers ca $0.5 \times 0.3 \mathrm{~mm}$, ovate, with apical round membranaceous appendage just covering the style-head apex. Pollinia 470-520 $\times 200-240 \mu \mathrm{m}$, oblong, with a round base and apex; pellucid margin missing; caudicles ca $130 \times 70 \mu \mathrm{m}$, ovoid, almost transparent; corpusculum 300-320 $\times$ 160-180 $\mu \mathrm{m}$, ovoid; style-head 5-angled in cross section, with five spreading lobes alternating with the stamens, style-head apex conical, 1-1.2 $\mathrm{mm}$ high, $0.9-1.1 \mathrm{~mm}$ in diameter at the base, apex acute; ovary 1.5-1.7 mm high, conical, with apex acute. Fruit and seed not observed.

\section{Distribution and habitat}

Hoya solokensis sp. nov. is only known from the type locality in Solok, Sumatra, Indonesia, at ca $1000 \mathrm{~m}$ a.s.l. It was collected in an evergreen forest, where it was growing epiphytically.

\section{Conservation status}

Known only from a single collection and lacking information on the distribution area, the population size and the possible threats to the habitat, H. solokensis sp. nov. is considered as Data Deficient (DD) (IUCN 2012).

\section{Notes}

Hoya solokensis sp. nov. is one of the few species of Hoya that exhibits a non-climbing habit but is instead an epiphytic shrub. It is morphologically similar to H. papaschonii Rodda (Rodda \& Ercole 2014), a species only found in southern Thailand. Both species share a shrubby habit, short-lived peduncles, and flowers with a tubular corolla. However, H. papaschonii has the free part of the corolla lobes mostly held upright, while in $H$. solokensis sp. nov. the lobes are spreading; furthermore, the corona of $H$. papaschonii has both staminal and interstaminal elements while $H$. solokensis sp. nov. only has a staminal corona. Another species with a tubular corolla is H. telosmoides Omlor (1996) from Borneo, that is, however, a climber. The flowers of $H$. solokensis sp. nov. superficially resemble those of the Bornean H. hamiltoniorum A.L.Lamb, Gavrus, Emoi \& Gokusing (Lamb et al. 2014) because both species have the free part of the corolla lobes spreading, however H. hamiltoniorum is a climber and its inner apex of the corona lobe is bifid, while the apex of the inner lobes of H. solokensis sp. nov. is entire.

\section{Hoya sumatrana S.Rahayu \& Rodda sp. nov.} urn:lsid:ipni.org:names:77195002-1

Figs $3-4$

\section{Etymology}

The new species is named after the Indonesian island of Sumatra.

\section{Type material}

Holotype

INDONESIA • Sumatra, Lampung, Taman Nasional Bukit Barisan Selatan, Tambling; 20 Sep. 2013; S. Rahayu 861 leg.; lowland forests; BO.

\section{Isotype}

INDONESIA • Same data as for the holotype; SING. 


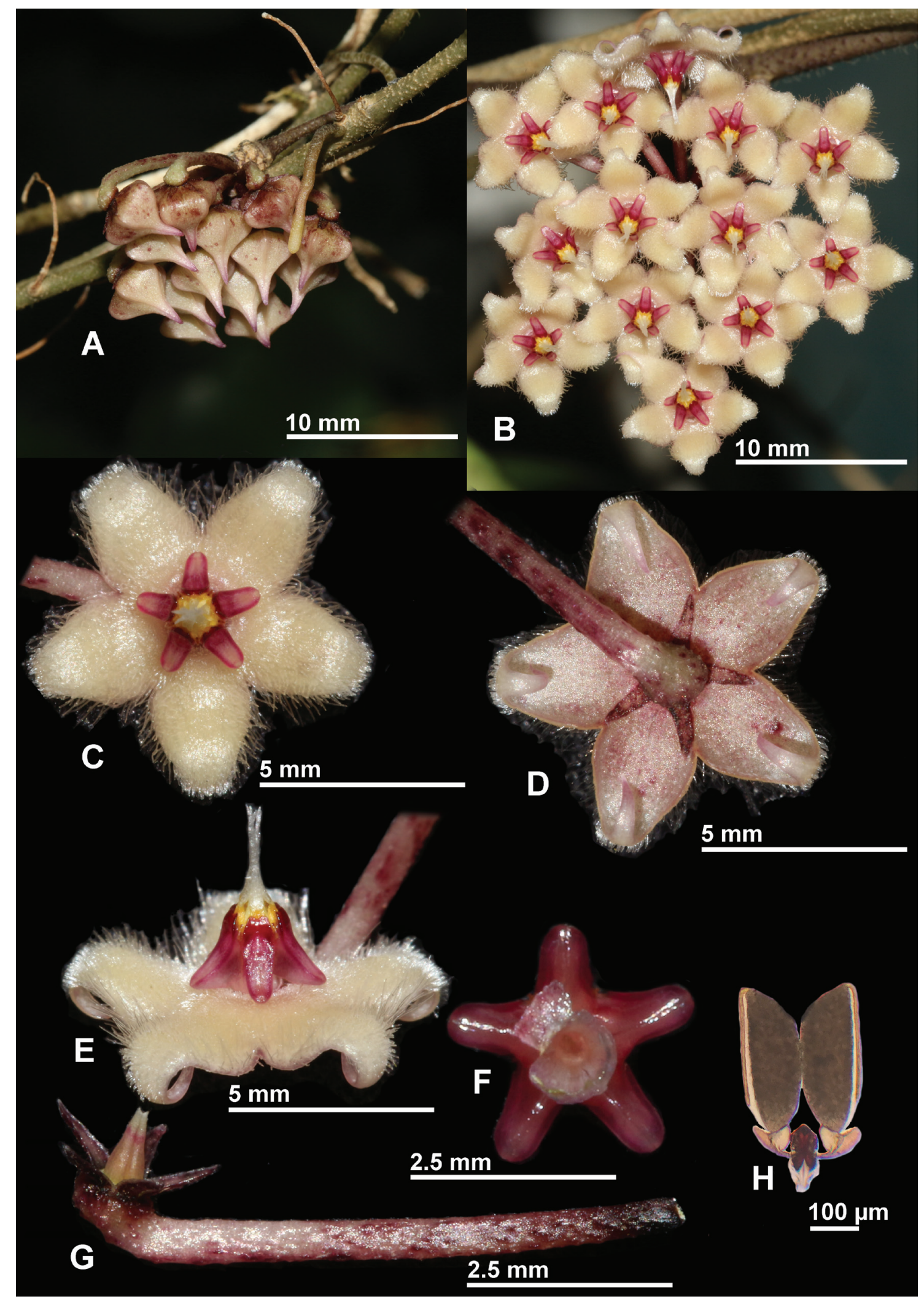

Fig. 3. Hoya sumatrana S.Rahayu \& Rodda sp. nov. A. Buds. B. Inflorescence, from underneath. C. Flower, from top. D. Corolla, from underneath, calyx and pedicel. E. Flower, side view. F. Corona, from underneath. G. Pedicel, calyx and ovaries. H. Pollinarium. Photos: M. Rodda. 


\section{Description}

Epiphytic climber, with white or yellowish latex in all vegetative parts. Roots adventitious below the nodes and along the internodes. Stems $2-4 \mathrm{~mm}$ in diameter, climbing, dull green, pubescent; older stems grey, glabrescent; internodes 2-5(10) cm. Leaf blades 3-7(15) × 3.5-5.5 cm, stiff and succulent, oblong, ovate or elliptic, base round to attenuate, apex acute, mid green on adaxial surface with sparse grey spots, pale green on abaxial surface, glabrous, or very sparsely pubescent when young, venation pinnate, inconspicuous, basal colleter ca $1 \times 1.5 \mathrm{~mm}$, one at each lamina base, broadly triangular, pale brown; petioles $10-20 \times 3-6 \mathrm{~mm}$, terete, dark brown, sparsely pubescent when young. Inflorescences $2.5-3 \mathrm{~cm}$ in diameter, of 10-15 flowers, sciadioidal, flat; peduncles 15-35 × 1.5-2 mm, extra-axillary, positively geotropic, 1 at each node, producing flowers over an extended period of time, terete, dark red, sparsely pubescent. Flowers with terete pedicels $5-15 \times 0.7-1 \mathrm{~mm}$, dark red at the base, fading to pale pink towards the calyx, sparsely papillose. Calyx lobes narrowly triangular, spaced $0.6-0.8 \mathrm{~mm}$ apart, apex acute or rounded, $1.4-2 \times 0.5-0.8 \mathrm{~mm}$, reddish, papillose outside, inside glabrous, sparsely ciliate; basal colleters $0.16-0.18 \times 0.09-0.11 \mathrm{~mm}$, one at each calyx sinus, ovoid. Corolla $7-9 \mathrm{~mm}$ in diameter when flattened, rotate; tube ca $1.5 \mathrm{~mm}$ long, cream, glabrous outside, densely pubescent inside; lobes triangular, valvate in bud, with recurved edges and revolute tip, 5-6 $\times 2-3 \mathrm{~mm}$, glabrous outside, densely pubescent inside with a glabrous tip ca $1.5 \mathrm{~mm}$ long. Corona staminal $2-2.5 \mathrm{~mm}$ high, $2.8-3.2 \mathrm{~mm}$ in diameter, red; lobes ca $2.2 \times 0.8 \mathrm{~mm}$, attached at the back of the anthers, held at ca $60^{\circ}$ angle, ovoid, slightly carinate

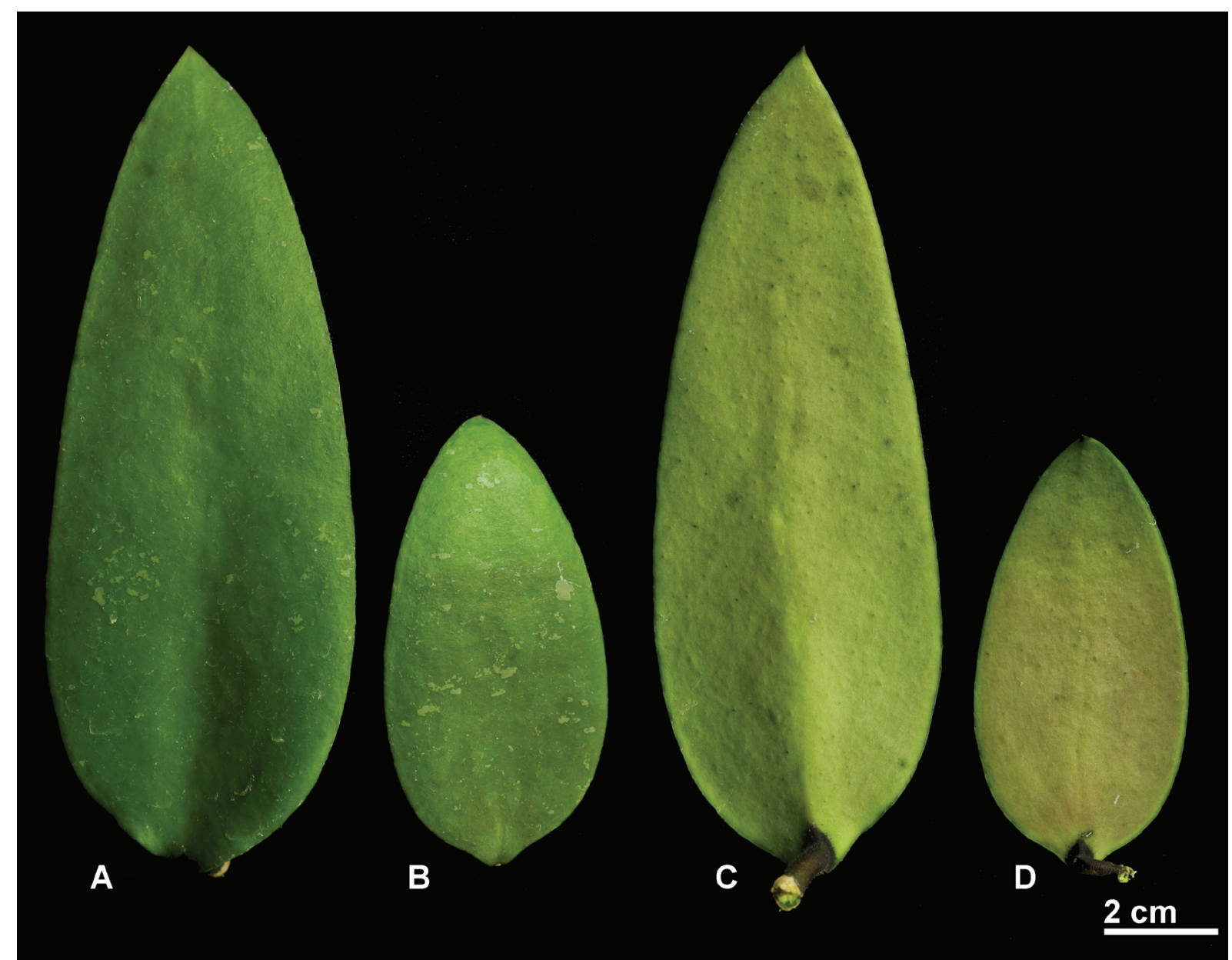

Fig. 4. Hoya sumatrana S.Rahayu \& Rodda sp. nov. A-B. Leaves from above. C-D. Leaves from from underneath. Photos: M. Rodda. 
above, inner process bilobed, outer process rounded, with a narrow basal revolute margin. Anthers ca $0.5 \times 0.4 \mathrm{~mm}$, ovate, with a linear apical round membranaceous appendage to $2.8 \mathrm{~mm}$ long. Pollinia 280-320 $\times 100-120 \mu \mathrm{m}$, oblong, with a round base and obliquely truncate; pellucid margin all along the outer edge; caudicles 100-120 × $70 \mu \mathrm{m}$, broad, almost transparent; corpusculum 90-110 × 40-60 $\mu \mathrm{m}$, oblong; style-head 5-angled in cross section, with five spreading lobes alternating with the stamens, style-head apex $0.8-0.9 \mathrm{~mm}$ long, $0.4-0.5 \mathrm{~mm}$ broad at the base, conical, with apex acute; ovary 1.5-2 $\times$ ca $0.5 \mathrm{~mm}$ at the base, conical, with apex acute. Fruit and seed not observed.

\section{Distribution and habitat}

Hoya sumatrana sp. nov. is only known from the type locality in in Lampung, Sumatra, Indonesia. It was collected in a coastal swamp forest, where it was growing as an epiphyte.

\section{Conservation status}

Known only from a single collection and lacking information on the distribution area, the population size and the possible threats to the habitat, H. sumatrana sp. nov. is considered as Data Deficient (DD) (IUCN 2012).

\section{Notes}

Hoya sumatrana sp. nov. is a new species in H. sect. Peltostemma Schlechter (1916: 14), characterized by upright corona lobes, long linear anther appendages extending well above the style-head and pollinaria with well developed caudicle wings. This section includes six species, two of which, $H$. soidaoensis Kidyoo (2013) and H. phuwuaensis Kidyoo (2016), have been recently published. Hoya sumatrana sp. nov. can be separated from all other members of this section because its flowers are much smaller; for example, the corolla of $H$. sumatrana sp. nov. is 7-9 $\mathrm{mm}$ in diameter, while the corolla of the second smallest species, H. flagellata Kerr (1940: tab. 3407), is $>10 \mathrm{~mm}$ in diameter, as well as the corona of Hoya sumatrana sp. nov. is $2.8-3.2 \mathrm{~mm}$ in diameter, while that of H. flagellata is $>4 \mathrm{~mm}$ in diameter. Another useful character to separate H. sumatrana sp. nov. from all other members of the section is the inner corona lobe process, that is bilobed in H. sumatrana sp. nov., while the other species have acute or rounded processes.

\section{Hoya uncinata Teijsm. \& Binn.}

Natuurkundig Tijdschrift voor Nederlandsch Indië 25: 408 (Teijsmann \& Binnendijk 1863).

\section{Synonym}

H. padangensis Schltr., Beihefte zum Botanischen Centralblatt 34 (2): 15 (Schlechter 1916). Type: INDONESIA • Sumatra, auf Bäumen bei Padang; 900 m a.s.l.; 20 Jan. 1907; R. Schlechter 15916 leg.; B100277224 (lectotype, designated by Rodda \& Rahayu 2018).

\section{Original citation}

"In silvis Javae et Sumatrae ins. prov. Palembang" (type material not traced).

\section{Type material}

Neotype (designated by Rodda \& Rahayu 2018)

INDONESIA • Sumatra, “auf Bäumen bei Padang”; 900 m a.s.1.; 20 Jan. 1907; R. Schlechter 15916 leg.; B100277224. 


\section{Hoya verticillata (Vahl) G.Don}

A General History of the Dichlamydeous Plants 4: 128 (Don 1837) - Sperlingia verticillata Vahl, Skrivter af Naturhistorie-Selskabet 6: 113 (Vahl 1810).

\section{Type material}

Lectotype (designated by Veldkamp et al. 1995)

INDIA • "Hb. Vahlii. Cynanchum? Floer ex Ind. Orient.”; C10006735.

\section{Possible isolectotype}

INDIA • “Hb. Vahlii. Sperlingia tetraphylla Cynanchum? Floer ex Ind. Orient.”; C10006736.

\section{Hoya vitellinoides Bakh.f.}

Blumea 6: 381 (Bakhuizen van den Brink 1950).

\section{Type material}

\section{Holotype}

INDONESIA • Java, Gunung Tjipoeli bij Tjampea; 800 m a.s.1.; 24 Sep. 1920; Bakhuizen van den Brink 4181 leg.; L0004347.

\section{Hoya vitellina Blume}

Museum Botanicum Lugduno-Batavum 1: 45 (Blume 1849a).

\section{Type material}

Lectotype (designated by Rodda 2017)

INDONESIA • West Java; C. L. Blume [?] s.n. leg.; L0004346.

\section{Possible isolectotypes}

INDONESIA • Same data as for the lectotype; BO1869758, BO1869758, U1102651.

\section{Hoya wrayi King \& Gamble}

Journal of the Asiatic Society of Bengal 74 (2): 579 (King \& Gamble 1908).

\section{Type material}

Lectotype (designated by Rodda \& Simonsson Juhonewe 2012)

MALAYSIA • Perak, Gunong Batu Pateh; 4300 ft; Wray 371 leg.; K.

Epitype (designated by Rodda \& Simonsson Juhonewe 2012)

MALAYSIA • Pahang, Fraser Hill; Feb. 1976; R.E. Rintz RER23 leg.; K (spirit material).

\section{Isoepitype}

MALAYSIA • Same data as for the epitype; K (pressed material). 


\section{Discussion}

Since Rahayu \& Wanntorp (2012), the Sumatran specimens identified as H. erythrostemma Kerr (1939) have been identified as $H$. rintzii, $H$. micrantha Hook.f. (Hooker 1883) has been re-determined as $H$. rundumensis, and $H$. verticillata was reported as $H$. parasitica Wall. ex Wight (1834). Nine species have been added to the inventory of Sumatran Hoya (Rahayu \& Wanntorp 2012), all described based on Sumatran collections. These are H. andalensis, H. beccarii, H. brooksii, H. deykeae, H. omlorii, $H$. parvifolia, $H$. purpurascens, $H$. sarcophylla, and $H$. uncinata.

Hoya variifolia is considered a new synonym of $H$. parviflora. Two further species, $H$. glabra Schltr (Schlechter 1908) and H. kastbergii, are newly recorded.

The total count of taxa of Hoya known from Sumatra now stands at 43 and includes 41 species and two subspecies.

\section{Acknowledgments}

We thank the directors and curators of the B, BO, BM, K, and SING herbaria for loans of specimens and access to the material studied. The National Parks Board Singapore is acknowledged for supporting numerous study trips to herbaria in SE Asia and Europe (MR). We are very grateful to Amar Husein Sitompul and Fadly for collecting some of the specimens cited in the paper, and to Dr. Frederik Leliaert, Dr. Koen Martens and Dr. Alejandro Quintanar for their editorial work on the paper.

\section{References}

Anonymous 2001. Our cover story: Genus Eriostemma (Schlechter) Kloppenburg \& Gilding. Fraterna 14 (2): $1-4$.

Anonymous 2003. New Borneo Hoya species. Fraterna 16 (4): 1-5.

Anonymous 2005. Hoya andalensis Kloppenburg. Fraterna 18 (1): 1-5.

Bakhuizen van den Brink R.C. 1950. Notes on the Flora of Java, VI. Blumea 6: 363-406.

Blume C.L. 1823. Catalogus van eenige der merkwaardigste zoo in-als uit-heemsche gewassen, te vinden in 's lands plantentuin te Buitenzorg. Ter Lands Drukkerij, Batavia.

Blume C.L. 1826. Bijdragen tot de flora van Nederlandsch Indië. Ter Lands Drukkerij, Batavia.

Blume C.L. 1849a. Museum Botanicum Lugduno-Batavum. Vol. 1. E.J. Brill, Lugdunum, Batavia.

Blume C.L. 1849b. Rumphia. Vol. 4. C.G. Sulpke, Leiden, Amsterdam.

Brown R. 1810. Prodromus Florae Novae Hollandiae et Insulae Van Diemen. Richard Taylor et al., London. https://doi.org/10.5962/bhl.title.3633

Decaisne J. 1838. Etudes sur quelques genres et espècies de la famille des Asclepiadees. Annales des Sciences naturelles, Botanique, sér. 2, 9: 257-278.

Decaisne J. 1844. Asclepiadeae. In: de Candolle A.L.P.P. (ed.) Prodromus Systematis Naturalis Regni Vegetabilis 8: 490-665. Fortin, Masson et sociorum, Paris.

Don G. 1837. A General History of the Dichlamydeous Plants. Vol. 4. J.G. Rivington and F. Rivington, London.

Forster P.I. \& Liddle D.J. 1992b. Taxonomic studies on the genus Hoya R.Br. (Asclepiadaceae) in Papuasia 4. Typification and synonymy of Hoya revoluta Wight ex J.D. Hook. Austrobaileya 3: 638-639. 
Green T. 2000. Hoya deykei Green sp. n. (Asclepiadaceae). Fraterna 13 (1): 15-16.

Green T. 2004. Our Cover Story. Hoya sigillatis Green (Asclepiadaceae Sp. Nova. Fraterna 17 (3): 2-4.

Green T. 2010. New subspecies of Hoya from Rundum, Sabah, Malaysia. Asklepios 108: 19-21.

Hasskarl C. 1843. Adnotationes de Plantis quibusdam Javanicis nonnullisque japonicis, haud rite cognitis, e Catalogo Horti Bogoriensis excerptae. Accedunt nunnullae Novae Species. In: van der Hoeven J. \& De Vriese W.H. (eds.) Tijdschrift voor Natuurlijke Geschiedenis en Physiologie 10: 115-150.

Heynhold J. 1840. Nomenclator Botanicus Hortensis. Arnold'schen Buchhandlung, Dresden.

Hooker J.D. 1883. The Flora of British India 4: 1-78. L. Reeve, London.

Hooker W.J. 1850. Hoya purpureofusca. Botanical Magazine 76: tab. 4520.

IUCN 2012. IUCN Red List Categories and Criteria (version 3.1, $2^{\text {nd }}$ edition). IUCN, Gland, Switzerland and Cambridge, UK.

Kerr A.F.G. 1939. Contributions to the Flora of Siam. Additamentum LII. Bulletin of Miscellaneous Information 1939: 456-465. https://doi.org/10.2307/4113547

Kerr A.F.G. 1940. Hoya mitrata \& Hoya flagellata. Hooker's Icones Plantarum 35: tab. 3406-3407.

Kidyoo M. 2013. Hoya soidaoensis (Apocynaceae: Asclepiadoideae), a new species from southeastern Thailand. Phytotaxa 105 (2): 45-50. https://doi.org/10.11646/phytotaxa.105.2.3

Kidyoo M. 2016. Hoya phuwuaensis (Apocynaceae: Asclepiadoideae), a new species from Northeastern Thailand. Phytotaxa 282 (3): 218-224. https://doi.org/10.11646/phytotaxa.282.3.5

King G. \& Gamble J. 1908. Flora of the Malayan Peninsula. Journal of the Asiatic Society of Bengal 74 (2): 559-580.

Kleijn D. \& van Donkelaar R. 2001. Notes on the taxonomy and ecology of the genus Hoya (Asclepiadaceae) in Central Sulawesi. Blumea 46: 457-483.

Kloppenburg R.D 2001. New Synonyms and Combinations. Fraterna 14 (1): 11-14.

Lamb A. \& Rodda M. 2016. A Guide to Hoyas of Borneo. Natural History Publications Borneo, Kota Kinabalu.

Lamb A., Gavrus A., Emoi B. \& Gokusing L. 2014. The Hoyas of Sabah, a commentary with seven new species and a new subspecies. Sandakania 19: 1-89.

Lindley J. 1846. New garden plant. Hoya imperialis. Edwards's Botanical Register 32: tab. 68.

Meve U., Laurente O., Alejandro G.J. \& Livschultz T. 2009. Systematics of Clemensiella (Apocynaceae - Asclepiadoideae). Edinburgh Journal of Botany 66 (3): 447-457. https://doi.org/10.1017/S0960428609990059

Miquel F.E.W. 1857. Flora van Nederlandsch Indië. Vol. 2. C.G. van der Post, Amsterdam.

Omlor R. 1996. Notes on Marsdenieae (Asclepiadaceae): A new, unusual species of Hoya from Northern Borneo. Novon 6: 288-294. https://doi.org/10.2307/3392096

Rahayu S. \& Wanntorp L. 2012. Notes on the species diversity of Hoya (Apocynaceae-Asclepiadoideae) of Sumatra. Asklepios 113: 17-26.

Ridley H.N. 1917. Spermatophyta and Pterydophyta. Journal of the Federated Malay States Museums 8 (4): 13-136.

Ridley H.N. 1923. A botanical excursion to northern Sumatra. Journal of the Malayan Branch of the Royal Asiatic Society 1: 46-113. 
Ridley H.N. 1925. Plants from Bencoolen, Sumatra. Collected by Mr. C.J. Brooks. Bulletin of Miscellaneous Information 1925: 76-94. https://doi.org/10.2307/4107521

Ridley H.N. 1926. The Flora of the Mentawi Islands. In: Boden Kloss C., Spolia Mentawiensia. Bulletin of miscellaneous information, Royal Gardens, Kew 1926: 57-94.

Rintz R.E. 1978. The Peninsular Malaysian species of Hoya (Asclepiadaceae). Malayan Nature Journal 30: 467-522.

Rodda M. 2017. Index of names and types of Hoya (Apocynaceae: Asclepiadoideae) of Borneo. Gardens' Bulletin Singapore 69 (1): 33-65. https://doi.org/10.26492/gbs69(1).2017-02

Rodda M. \& Ercole E. 2014. Hoya papaschonii (Apocynaceae: Asclepiadoideae), a new species from southern Thailand with a peculiar corona. Phytotaxa 175 (2): 97-106. https://doi.org/10.11646/phytotaxa.175.2.4

Rodda M. \& Nyhuus T. 2009. Hoya danumensis, a new species of Hoya (Apocynaceae, Asclepiadoideae) from Borneo. Webbia 64: 163-167. https://doi.org/10.1080/00837792.2009.10670856

Rodda M. \& Rahayu S. 2018. A revision of the Hoya uncinata complex (Apocynaceae, Asclepiadoideae), with description of a new species. Phytotaxa 383 (3): 252-258. https://doi.org/10.11646/phytotaxa.383.3.2

Rodda M. \& Simonsson Juhonewe N. 2012. Hoya somadeeae sp. nov. (Apocynaceae, Asclepiadoideae) Thailand and lectotypification of Hoya wrayi. Nordic Journal of Botany 30: 578-584. https://doi.org/10.1111/j.1756-1051.2011.01400.x

Rodda M. \& Simonsson Juhonewe N. 2013. The taxonomy of Hoya micrantha and Hoya revoluta (Apocynaceae, Asclepiadoideae). Webbia 68: 7-16. https://doi.org/10.1080/00837792.2013.802937

Rodda M., Simonsson Juhonewe N. \& Rahayu S. 2014. Taxonomic revision of the Hoya mindorensis complex (Apocynaceae: Asclepiadoideae). Webbia 69: 39-47. https://doi.org/10.1080/00837792.2014.900261

Rodda M, Simonsson Juhonewe N. \& Middleton D.J. 2016. The taxonomic status of the presumed extinct Singaporean Hoya wallichii (Apocynaceae: Asclepiadoideae). Gardens' Bulletin Singapore 68: $175-187$.

Rodda M., Lamb A.L., Gokusing L. \& Rahayu S. 2018. Hoya fauziana ssp. angulata (Apocynaceae, Asclepiadoideae), a new subspecies from Borneo and Sumatra. Blumea 63: 144-146. https://doi.org/10.3767/blumea.2018.63.02.10

Rumphius G.E. 1747. Herbarium Amboinense. Vol. 5. J. Burman, Amsterdam.

Schlechter R. 1908. Beiträge zur Kenntnis der Asclepiadaceen des Monsun-Gebietes. Botanische Jahrbücher für Systematik, Pflanzengeschichte und Pflanzengeographie 40 (92): 1-19.

Schlechter R. 1916. Neue Asclepiadaceen von Sumatra und Celebes. Beihefte zum Botanischen Centralblatt 34 (2): 1-18.

Teijsmann J.E. \& Binnendijk S. 1863. Plantae novae in horto bogoriensi cultae. Natuurkundig Tijdschrift voor Nederlandsch Indië 25: 399-428.

Teijsmann J.E. \& Binnendijk S. 1866. Catalogus Plantarum quae in Horto Botanico Bogoriensi coluntur. Lands-Drukkerij, Buitenzorg, Batavia.

Thiers B. 2019. Index Herbariorum: A Global Directory of public Herbaria and associated Staff. New York Botanical Garden's Virtual Herbarium, New York. Available from http://sweetgum.nybg.org/science/ih/ [accessed 13 Feb. 2019]. 
Turner I.M., Low Y.W., Rodda M., Wong K.M. \& Middleton D.J. 2018. The plant taxa of H.N. Ridley, 5. The Gentianales. Gardens' Bulletin Singapore 70 (2): 307-395. https://doi.org/10.26492/gbs70(2).2018-08

Vahl M. 1810. Beskrivelse over nye Planteslægter. Skrivter af Naturhistorie-Selskabet 6: 84-128.

Wanntorp L. \& Meve U. 2011. New combinations in Hoya for the species of Clemensiella (Marsdenieae, Apocynaceae). Willdenowia 41: 97-99. https://doi.org/10.3372/wi.41.41110

Veldkamp J.F., van Donkelaar R. \& Kloppenburg R.D. 1995. The identity of Sperlingia Vahl (Asclepiadaceae). Blumea 40: 425-428.

Wight R. 1834. Contributions to the Botany of India. Parbury, Allen et al., London.

Manuscript received: 30 July 2018

Manuscript accepted: 21 January 2019

Published on: 23 March 2019

Topic editor: Frederik Leliaert

Desk editor: Alejandro Quintanar

Printed versions of all papers are also deposited in the libraries of the institutes that are members of the EJT consortium: Muséum national d'Histoire naturelle, Paris, France; Meise Botanic Garden, Belgium; Royal Museum for Central Africa, Tervuren, Belgium; Royal Belgian Institute of Natural Sciences, Brussels, Belgium; Natural History Museum of Denmark, Copenhagen, Denmark; Naturalis Biodiversity Center, Leiden, the Netherlands; Museo Nacional de Ciencias Naturales-CSIC, Madrid, Spain; Real Jardín Botánico de Madrid CSIC, Madrid, Spain; Zoological Research Museum Alexander Koenig, Bonn, Germany. 